\title{
Under the Shadow of the Axe
}

from our Washington Correspondent

THERE is a general air of gloom and uncertainty pervading the federal departments and agencies in Washington which have dealings with science and technology, and the mood is unlikely to lighten much in the next few months. The most immediate cause for concern is the likelihood that in the next week or two the Office of Management and Budget will send out an order directing federal officials not to spend some of the money which they have already committed for the present fiscal year. The second cause for gloom is that the season for putting the finishing touches to the 1974 budgets has now arrived, and all indications point towards a period of financial famine. Finally, the much-publicized post-election shake-up of the White House staff had not at the beginning of this week reached the
Office of Science and Technology, but rumours are rampant.

The impending budget cuts for the present fiscal year, which is now halfway through, will be a direct result of President Nixon's much repeated promise to hold federal spending down to $\$ 250,000$ million in order not to increase taxes next year. According to a study published last month by the Brookings Institution, he will have to cut about $\$ 6,000$ million from existing programmes if he is going to meet the target, but all the cuts must come from programmes which together account for about $\$ 72,000$ - the rest of the budget goes to relatively uncontrollable items such as pensions and federal salaries.

Unfortunately, programmes involving science and technology are likely to suffer particularly prominently from the Administration's knife, for they nearly all fall in the controllable cate-

\section{CANCER RESEARCH MIT Branches Out}

from our Washington Correspondent

THE Massachusetts Institute of Technology, for long a bastion of engineering and the physical sciences, is branching out into cancer research in a big way. It was announced last week that the National Cancer Institute has given MIT a grant of $\$ 2,362,500$ to help set up a Center for Cancer Research where some 60 professional scientists and technical assistants will eventually work on tumour virology, immunology, cell biology and cell development. The centre, which will be headed by $\mathrm{Dr}$ Salvador E. Luria, will be the first major cancer research institution in the United States not directly connected to a hospital or medical school.

Why MIT? One good reason is that the institute itself has provided a building on its East Campus and \$1.8 million towards converting and renovating it. Another is that MIT has, over the past decade or so, built up considerable expertise in cancer research and basic cell biology, with Dr David Baltimore, Dr Phillips Robbins, Dr Alexander Rich and Dr Luria particularly prominent.

Work on reconstructing the building will begin on January 1 next year, and it is hoped that two floors will be occupied by October 1973. The rest should be ready by May 1974 and when completed, the centre will have about 35,000 square feet of research and office space. The National Cancer Institute will provide $\$ 136,376$ for the first year of operation and $£ 1.89$ million for 3 more years.

Apart from the appointment of $\mathrm{Dr}$ Luria to head the centre, the only other staff member who has so far been confirmed is Dr David Baltimore, who will move his tumour virology research over to the centre next year. Dr Luria also said last week that "a very prominent cancer immunologist" will be joining the centre next year, but his appointment must await confirmation by the faculty board when it meets in January.

Asked last week what type of research will be performed at the centre, Dr Luria said that virology and immunology will be followed in the second year of operation by cell biology and cell development-the thrust of the research will be basic cancer biology and biochemistry. "A man-on-themoon approach" to cancer research would be appropriate, Dr Luria said, "only when the basic knowledge is available. We do not have that knowledge in cancer-much more basic research is needed". As for clinical studies, Dr Luria said that although none is planned for the first three years of operation, researchers at the centre will be working on clinical materials, mostly supported through the HarvardMIT Medical Program. gory. The Administration's cost cutting has, in fact, already affected several science programmes which have been approved by Congress-Nixon has twice vetoed the HEW Appropriations bill, refused to sanction bills designed to set up a National Institute on Aging, and to encourage mining research, and he tried in vain to block the Water Pollution Control Bill-but the scientific community clearly faces further belt tightening in the coming months.

If the Office of Management and Budget does hack a large slice off the 1973 fiscal year budgets, the effect would be particularly severe, because some of the cuts would be made in programmes for which grants or contracts have already been let. According to an article in the November issue of sppsg, a science policy newsletter published by MIT, the Administration has the power to withhold funds appropriated by Congress under the Anti-Deficiency Act of 1870 , but if the OMB's actions lead to a government refusal to honour some contracts let in good faith, it can be safely assumed that such an action would be contested in the courts.

What effect is all this short-term financial stringency likely to have on the 1974 budget, which is due to be unveiled next month? At present, there can be little doubt that academic science is in for a thin time. Federal expenditure during the past three years has been higher than at any time since the Second World War, and the Administration will certainly take some drastic steps to hold it down next year. On the other hand, however, according to the Brookings Institution study, there will be a built-in uncontrollable increase in federal spending next year of some $\$ 20,900$ million, including an estimated $\$ 9,200$ million increase in social security. Moreover, any hopes that the possible ending of the Vietnam war would lead to a decline in the budget of the Department of Defense were dashed last week when Mr Melvin Laird announced that salary and other cost increases would require a budget for the DoD of more than $\$ 80,000$ million.

In the face of such uncontrollable increases in federal expenditure, it therefore seems likely that the controllable items in the budget will be hard pressed. Academic science, which falls in this category, and which also suffers to some extent from the desire for quick payoff, is therefore likely to continue to suffer for some time. 